\title{
Effects of Urban Metabolism on the Well Water Quality in Cotonou (Benin) and Lomé (Togo)
}

\author{
Henri S. Totin Vodounon ${ }^{1}$, Koko Z. Houedakor ${ }^{2}$, Ernest Amoussou ${ }^{1}$, Adrien C. Dossou-Yovo ${ }^{3}$ \\ ${ }^{1}$ Department of Geography and Territory Planning, University of Parakou, Parakou, Benin \\ ${ }^{2}$ Centre for Integrated Coastal and Environmental Management, University of Lomé, Lomé, Togo \\ ${ }^{3}$ Institute of Geography, Territory Planning and Environment, University of Abomey-Calavi, Cotonou, Benin \\ Email: *totinsourouhv@gmail.com, ajernest@yahoo.fr, koko.houedakor@gmail.com,dosadrien@yahoo.fr
}

How to cite this paper: Vodounon, H.S.T., Houedakor, K.Z., Amoussou, E. and Dossou-Yovo, A.C. (2021) Effects of Urban Metabolism on the Well Water Quality in Cotonou (Benin) and Lomé (Togo). Journal of Water Resource and Protection, 13, 539-562.

https://doi.org/10.4236/jwarp.2021.138030

Received: July 1, 2021

Accepted: July 25, 2021

Published: July 28, 2021

Copyright $\odot 2021$ by author(s) and Scientific Research Publishing Inc. This work is licensed under the Creative Commons Attribution International License (CC BY 4.0).

http://creativecommons.org/licenses/by/4.0/

\section{(c) (i) Open Access}

\begin{abstract}
Urban metabolism, a process of material, energy and water flows, consumption or transformation in the cities and outflows of wastes, has impacts on the shallow groundwater. This study addressed the relationship between the urban metabolic system and well water physicochemical and bacteriological quality in the coastal cities of Cotonou and Lomé. A participatory transdisciplinary approach, involving non-academics and academics stakeholders was used to analyse urban inflows and outflows related to groundwater quality. Standard methods were used to measure well water quality from 100 seasonal samples. Waste management revealed poor sanitation and hence a linear urban metabolism with no solid and liquid wastes and excreta recycling. This form of city metabolism reinforced by the seawater inflow is the main source of groundwater quality deterioration in Cotonou and Lomé. The principal water types $\mathrm{Ca}^{2+}-\mathrm{Mg}^{2+}-\mathrm{Cl}^{-}-\mathrm{SO}_{4}^{2-}$ (48.21\%), $\mathrm{Na}^{+}-\mathrm{K}^{+}-\mathrm{Cl}^{-}-\mathrm{SO}_{4}^{2-} \quad$ (65.9\%) and the Gibbs diagram suggested water-rock interactions and dominance of cations exchange on the hydrogeological compositions, also seasonally controlled by saltwater intrusion or anthropogenic salinization. The water quality index on the range of 35.90 to 169.60 in Cotonou and 82.94 to 364.68 in Lomé indicated well water very poor quality to unsuitable for drinking. Moreover, the bacteriological quality was bad due to total coliforms (112 - 1812; $1-1000$ UFC/100 mL respectively in Cotonou and Lomé), Escherichia coli (40 - 780; 1 - 112 UFC/100 mL), faecal enterococci/streptococcus (18 - 736; 1 - 118 UFC/100 $\mathrm{mL}$ ). The findings could help to sustain groundwater quality by controlling the pollution sources linked to urban metabolism.
\end{abstract}

\section{Keywords}

Transdisciplinary, Linear Urban Metabolism, Well Water Pollution, 


\section{Introduction}

The concept of urban metabolism borrows the biological definition of metabolism and applies it as a model to describe the way in which cities sustain their functions by transforming materials and energy [1]. More broadly, urban metabolism refers to the socio-ecological exchange processes and socio-natural transformations that take place in urban environments [2] like those of Africa. Depending on the mode of waste management, a city can be characterized by either a linear metabolism model (no waste recycling) or a circular metabolism model (waste recycling and reuse) [3] [4] [5]. A linear metabolism can be essentially characterized by a single use of resources in the city and their return to the environment in the form of waste [6]. The transition from linear to circular urban metabolism is not systematic. The nuance is a possible intermediate mode where there is recycling of some wastes, but the treatment is neither linear nor circular. Whatever the form, it has impacts on urban water systems.

In Africa, one of the fastest urbanizing regions around the world [7] [8], the key to tackling cities' challenges is an understanding of urban governance processes [9] much complex in the coastal areas due to their ecology. In West coast of Africa, the most densely populated region, the cities of Cotonou (Benin) and Lomé (Togo) can therefore each be considered as a "complex metabolic system with, following Bochet and Cunha [10], a set of inputs (raw materials, semi-finished products, food products, etc.), transformation (semi-finished or finished products) and outputs (liquid and solid wastes, excreta, etc.)". Then, focused on this last step of the urban metabolism, according to Deutsche Gesellschaft für Internationale Zusammenarbeit (GIZ) [11] in sub-Saharan Africa, the situation regarding water and sanitation is increasingly serious. So, the poor environmental governance associated with population growth and unplanned urbanization, is a major challenge to the shallow unconfined groundwater quality. As noted by the United Nations Environment Programme (UNEP) [12], a decline in water quality reduces its suitability for drinking and use in agriculture and other industries.

The easy access of shallow groundwater is the main interest of its quality assessment [13] particularly in the coastal urban areas of Cotonou and Lomé. Our transdisciplinary participatory approach involves all urban stakeholders in solving a societal problem, that is, the deterioration of well water quality by the inflows and outflows of materials and water on these cities. Using this research approach, the study assessed the footprints of water-related resources inputs and wastes outputs on the physicochemical and bacteriological quality of well water in the perspective of its protection in these coastal cities. The objective of the current study is to present the divers components of town metabolism and processes on Cotonou and Lomé. Secondary the purpose is to assess how the 
well water physicochemical and bacteriological quality is affected by metabolic processes based on resources inputs and wastes outputs.

\section{Materials and Methods}

\subsection{Study Area}

Cotonou and Lomé are selected as ideal cities for this study because they are respectively the most populous of Benin and Togo, and home to more than $50 \%$ of those countries' urban populations. They are both located in the coastal sandy and marshy plains between the Atlantic Ocean and the lagoons and lakes of West Africa (Figure 1). The cities of Cotonou and Lomé are established on sites that are $4-6 \mathrm{~km}$ long and $2-3 \mathrm{~km}$ long, respectively, and have relatively flat and irregular topographies (0.4 - $6.5 \mathrm{~m}$ in Cotonou, $5 \mathrm{~m}$ in Lomé) and are slightly inclined towards the south with a slope around $0.1 \%$. Soils are sandy, composed of $80 \%$ coarse sand, with a porosity exceeding $40 \%$ in Cotonou and an infiltration speed greater than $8.3 \times 10^{-5} \mathrm{~m} / \mathrm{s}$ [14]. These characteristics favor water infiltration and the transfer of contaminants from sewage, wastewater basins, landfills, latrines and natural sources (lake, lagoons, sea) towards shallow aquifers.

The two cities are located in a coastal sedimentary basin in West Africa. Cotonou is situated in a hydrogeological basin composed of Quaternary (Holocene) sediments and alluvial deposits, and Mio-Pliocene (Continental Terminal), Palaeocene and Upper Cretaceous sediments [15] that contain groundwater. In Lomé, aquifers are composed of Quaternary, Continental Terminal, Palaeocene (limestone) and Maastrichtian layers [16]. This study is mainly focused on the well water from the Quaternary sand unconfined aquifer, which has depths of 0 $5 \mathrm{~m}$ in Cotonou [17] and $0.5-3 \mathrm{~m}$ in Lomé [18]. These cities are in a sub-equatorial climate zone having two annual rainy seasons and two dry seasons. The monthly average rainfall is $109.6 \mathrm{~mm}$ in Cotonou and $37.5 \mathrm{~mm}$ in Lomé, and the average temperatures are 27.7 and $27.9^{\circ} \mathrm{C}$, respectively. In these hydroclimatic conditions, rapid decomposition of solid waste and drainage of wastewater occur, enhancing the ecological risk of aquifer contamination. The cities were poorly planned and contain many slums that lack basic socio-community infrastructure. Rapid population growth in Cotonou (1979: 320,348 inhabitants; 2019: 1,152,696 inhabitants) and in Lomé (1950: 33,000 inhabitants; 2019: 1,078,619 inhabitants) and high population density (14,591 inhabitants per $\mathrm{km}^{2}$ and 11,985 inhabitants per $\mathrm{km}^{2}$ ), has led to increased production of solid and liquid wastes and excreta. The challenge of access to safe drinking water raises due to high levels of anthropogenic pollution in groundwater. In the study areas, there are public water mains but in $88.91 \%$ of households, well water is an alternative when tap water is unavailable.

Urban sprawl and spatial saturation constrain people to live in a complex environment marked by improper waste management and leachate and faecal contamination of water sources. In such cases, the well-being of urban populations is affected by degraded groundwater quality. Paradoxically, communities in 


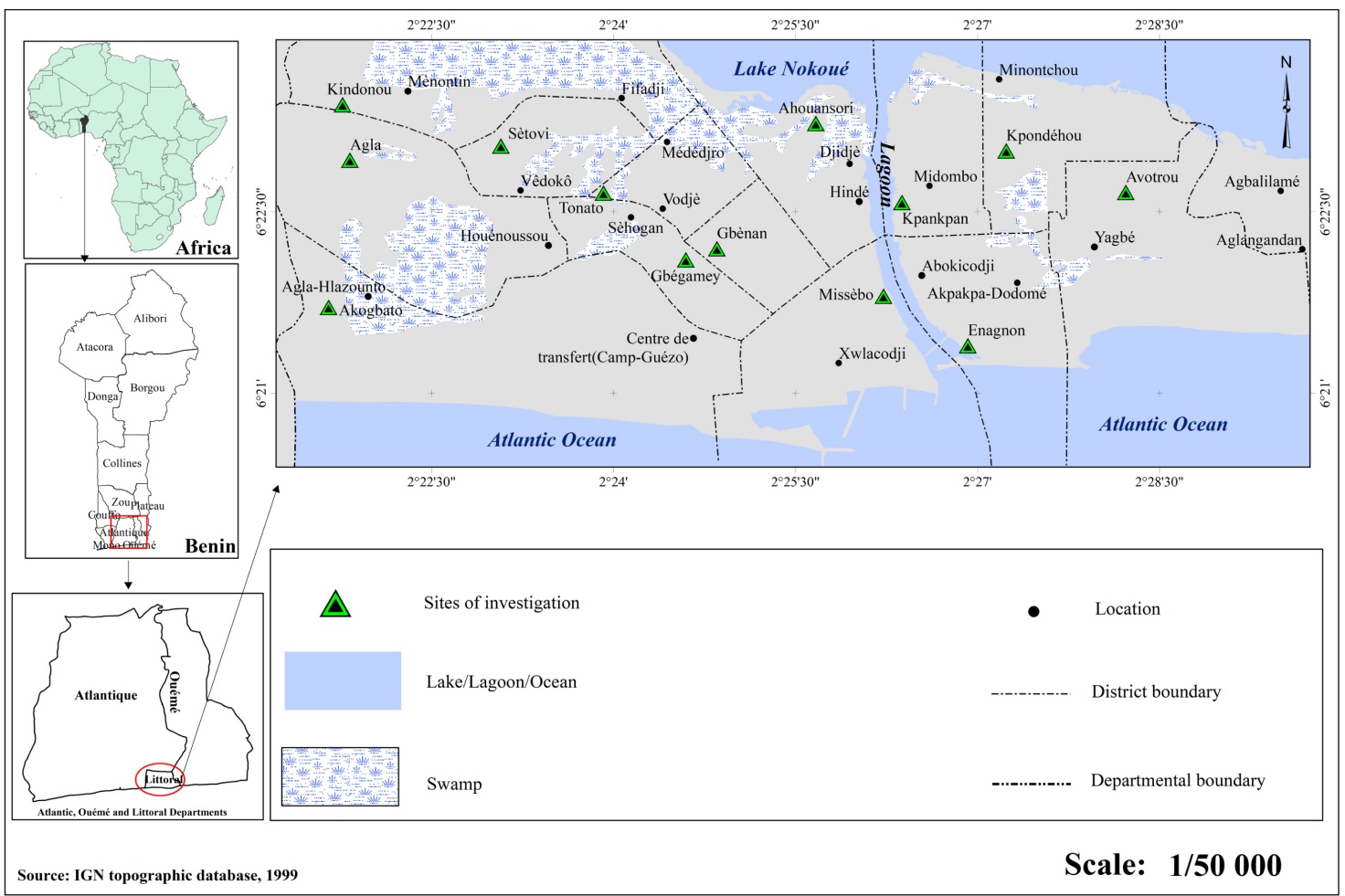

(a)

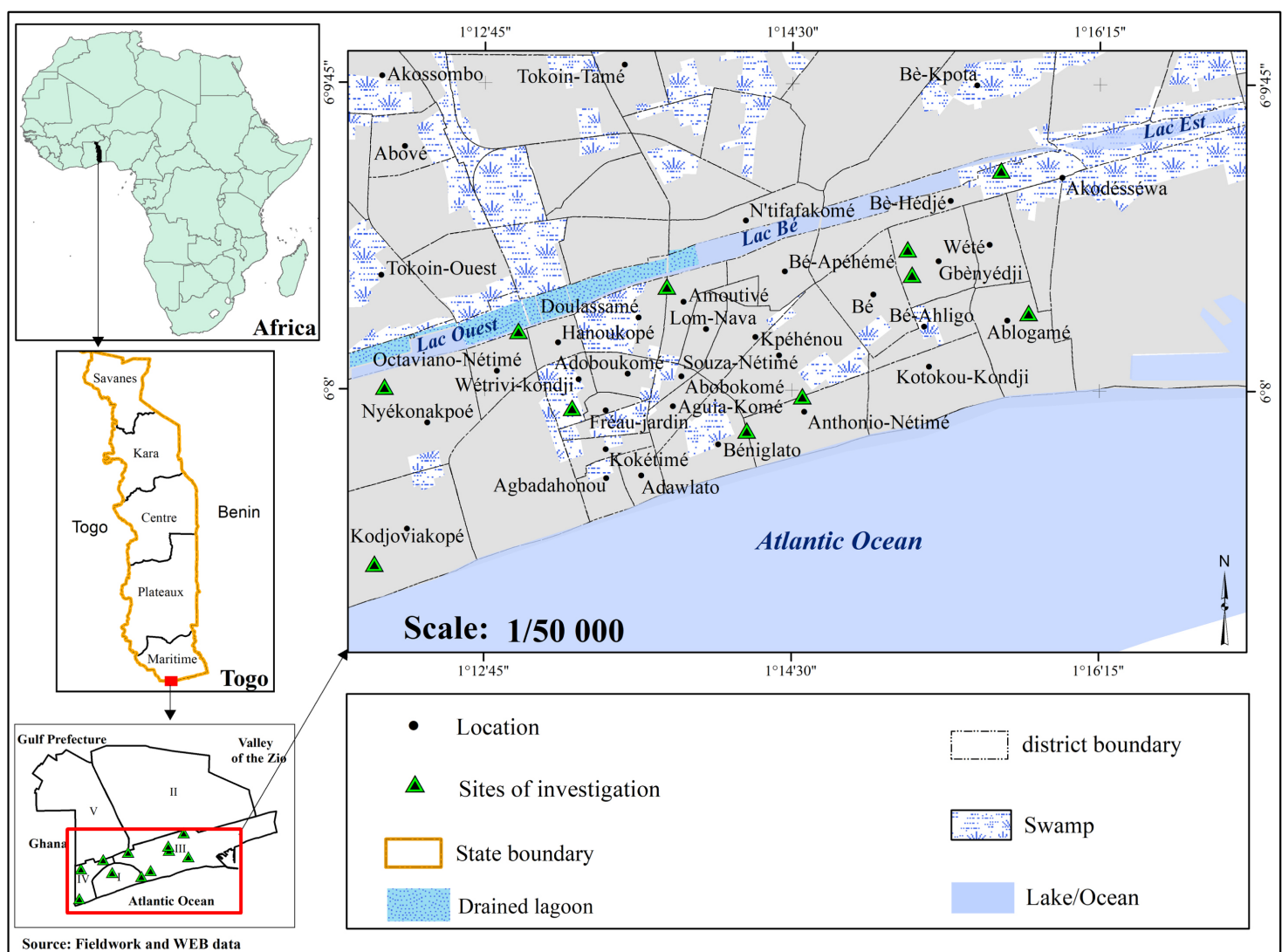

(b)

Figure 1. Geographical location of the cities of Cotonou (a) and Lomé (b) and domestic well water sampling sites. 
Cotonou and Lomé are located on area of shallow aquifers with water levels between 0.5 and $2 \mathrm{~m}$, and water available in abundance.

The link between the poor psychosocial perceptions of the cities' inhabitants and the urban water system lead us to explore the tracks of sociohydrology, the science of people and water [19] and of socio-hydrogeology, the mutual relations between people and groundwater [20] to carry this study including the social dimension in hydrogeological investigations.

\subsection{Participatory Transdisciplinary Approach and Analysis of Urban Metabolism}

The transdisciplinary objective of this study is to lead urban community-based stakeholders and scientists in evaluating and identifying the sources of domestic well water contamination, and to make them aware of the health risks linked to urban metabolism.

The present study was based on urban metabolism [4] [21] [22] [23] [24] but conducted using a transdisciplinary approach [25] [26] [27] [28]. The urban metabolism processes (inflows, regulation mechanisms and outflows) measured in Cotonou and Lomé were especially that interact with the urban water system like materials, food products and water (atmospheric, surface, groundwater and produced) inputs. The regulation system of inflows is analyzed in terms of resources consumption, transformation, transfer or storage during urbanization. This enable to evaluate outputs (e.g. solid waste, wastewater, excreta) from resources use into the urban water system, especially the shallow aquifers which provide domestic well water.

Taken transdisciplinary action [29] involved the non-academics and academics stakeholders from Cotonou and Lomé and their inclusive participation in all the steps of this study (problem framing, field data collection and analysis, discussion on the findings and publication of co-produced knowledge through a cognitive process for groundwater sustainability). In practical terms, our research consortium included academics geographers, sociologists, hydrogeologists, civil engineers, architects, specialists in public health, sanitation and hygiene, and urbanists as well as non-academic groups such as urban residents, business interest groups, civil society, government agencies working on Water Sanitation and Hygiene (WASH) and municipality offices, urban community government, and media and advertising agencies.

The formats of stakeholder engagement used are partnership, participation or consultation to facilitate co-design and co-produce knowledge on city change mechanism and its implications on groundwater quality on Cotonou and Lomé. The first step in engaging these diverse groups in a participatory research processes is to co-design the problems of groundwater quality degradation linked the inflows and outflows of matter, water and energy in the study areas. Our research consortium engagement in direct research facilitated the transdisciplinary coproduction of knowledge (by breaking the boundaries between non-academics and academics) on the impact of resources inflows versus wastes outflows and 
sanitation practices on groundwater quality. Research took the form of involving household members on the local field visits (collection of well water samples in clean and sterile bottles), observations on the status of the environment and wells, identification of the mechanisms of groundwater contamination. Thus group interviews were organized on 115 households per city to discuss on well water quality and co-assessment its quality. This engaged researcher-stakeholder group discussions enable to generate new knowledge, addressing the solution to the problem of city inflows/outflows and its effects of groundwater contamination. Data collected through the field visits were used to calculate the survey response rate (percentages of consensus responses from the household members) concerning the different points of the questionnaires.

Finally, the co-produced findings by the transdisciplinary approach is used to promote acceptable, affordable sanitation and hygiene practices and to improve the quality of groundwater and, ultimately, to solve the challenge of safe domestic well water.

This multi-stakeholder model guides us to a better understanding of the input and output of energy, water and matter, and solid, liquid and excreta waste management systems in Cotonou and Lomé and their ecological footprints on the quality of groundwater.

\subsection{Well Water Sampling}

The connectivity between social science and hydrogeochemical study bring re-searchers (academics) into contact with urban communities and well water users during the samples collection activities. This transdisciplinary approach gives, according to [20], a practical example of the concept of "sociohydrogeology", a way of incorporating the social dimension into hydrogeological investigations. Investigated neighborhoods were jointly selected according to the following criteria: people density, existence of a garbage dump, distance of the well to landfills or latrines (more or less than $15 \mathrm{~m}$ with regard to the urban land saturation), excreta disposal (pit latrine or septic tank) or swamps, lake and lagoon in connection with the Atlantic Ocean. Data on environmental factors, sanitation and hygiene practices, the use of well water were collected by field observations and questionnaire focus on the research thematic.

Differentiation of domestic well water quality against the source of contamination was assessed (involving local urban stakeholders) based on 14 seasonal water samples collected in Cotonou and 11 in Lomé (Figure 1) during the great rainy season (July 2019), small dry season (August 2019), small rainy season (October 2019) and the great dry season (December 2019).

\subsection{Water Physicochemical and Bacteriological Analysis}

Quality of well water was analyzed in the field and laboratory according to standard protocols [30] [31]. The compliance of water quality was assessed versus the drinking water standards of the World Health Organization (WHO) [32]. 
The physicochemical parameters of well water quality measured were temperature (T), pH, electrical conductivity (EC), Total dissolved solids (TDS) using the Multi 340i and pH/Cond 340i Handheld Multimeters. The turbidity is measured with the HACH DR-890 spectrophotometer. The concentrations of calcium $\left(\mathrm{Ca}^{2+}\right)$, magnesium $\left(\mathrm{Mg}^{2+}\right)$, sodium $\left(\mathrm{Na}^{+}\right)$, potassium $\left(\mathrm{K}^{+}\right)$, ammonium $\left(\mathrm{NH}_{4}^{+}\right)$, chloride $\left(\mathrm{Cl}^{-}\right)$, sulphate $\left(\mathrm{SO}_{4}^{2-}\right)$, nitrate $\left(\mathrm{NO}_{3}^{-}\right)$ions were assessed using the Dionex ICS-1000 Ion Chromatography System. The bicarbonate $\left(\mathrm{HCO}_{3}^{-}\right)$content was measured by titration with hydrochloric acid $(\mathrm{HCl})$ while the total hardness $(\mathrm{TH})$ was reported as of calcium carbonate $\left(\mathrm{CaCO}_{3}\right)$ equivalents.

Bacterial pollutants were identified in the samples using the membrane filter technique with specific culture media: Mac Conkey agar [for coliforms a Colony Forming Unit (CFU) checked after 24 to 48 hours of incubation at $44^{\circ} \mathrm{C}$ ], Slanetz and Bartley agar (for streptococcus) and Eosin methylene blue agar (EMB) (for enterobacteria such as Escherichia coli). Sulphite-reducing clostridia are enumerated using the tryptose-sulphite-cycloserine agar after anaerobic incubation at $44^{\circ} \mathrm{C} \pm 1^{\circ} \mathrm{C}$ for $21 \pm 3$ hours.

\subsection{Determination of Hydrochemical Types and Gibbs Diagram}

Hydrogeochemical types of the well water were determined from major cations and anions using Piper trilinear diagram [33], plotted with Diagrammes software 6.59 of the Hydrogeology Laboratory of Avignon, based on the major cations and anions.

The major factors controlling the hydrogeochemical compositions [13] [34] had been distinguish through Gibbs diagram which basis is the ratios $\left[\mathrm{Na}^{+} /\left(\mathrm{Ca}^{2+}\right.\right.$ $\left.\left.+\mathrm{Na}^{+}\right)\right]$and $\left[\mathrm{Cl}^{-} /\left(\mathrm{Cl}^{-}+\mathrm{HCO}_{3}^{-}\right)\right]$as a function of TDS. Gibbs [35] plot helps to appreciate the influences of rock-water interaction, evaporation and atmospheric precipitation (three natural fundamental processes) on water chemistry.

\subsection{Water Quality Index (WQI)}

The Water Quality Index (WQI) is computed based on the parameters $\mathrm{pH}$, TDS, $\mathrm{TH}, \mathrm{Ca}^{2+}, \mathrm{Mg}^{2+}, \mathrm{Na}^{+}, \mathrm{K}^{+}, \mathrm{Cl}^{-}, \mathrm{SO}_{4}^{2-}, \mathrm{HCO}_{3}^{-}$and $\mathrm{NO}_{3}^{-}$, adapted from Alastal et al. [36] and El Baba et al. [37] and the WHO [32] standards of drinking water quality to assess seasonal quality status. The relationships among those parameters is that they help to determine only the physicochemical quality status of well water.

The equations used to estimate WQI are:

$$
\mathrm{WQI}=\frac{\sum_{i=1}^{n} q_{i} W_{i}}{\sum_{i=1}^{n} W_{i}}
$$

With

$$
W_{i}=\frac{K}{S_{i}}
$$


$W_{i}$ is a unit weight factor.

$S_{i}$ is the standard value of $i^{\text {th }}$ parameter and $K$ a proportionality constant.

$$
K=\frac{1}{\sum_{i=1}^{n}\left(\frac{1}{S_{i}}\right)}
$$

Table 1 give the unit weights $W_{i}$ for the 11 selected parameters with standard values.

$q_{i}$ is a quality rating for $n^{\text {th }}$ water quality parameter is given by the equation:

$$
q_{i}=100 \cdot \frac{V_{i}-V_{0}}{S_{i}-V_{0}}
$$

$V_{i}$ and $S_{i}$ are respectively the estimated value and the standard permissible value of the $n^{\text {th }}$ parameters at a given sampling station.

$V_{0}=$ Ideal value of the $n^{\text {th }}$ parameter in pure water [ $V_{0}=0$ for all other parameters of the drinking water except the parameter $\mathrm{pH}(7.0)]$.

It not possible in this study to include selected bacteriological indicators in the WQI because the value 0 of $S_{i}$ can permit to calculate related parameters as $W_{i}$ and $\mathrm{K}$.

The categories of WQI are into five water quality status [38] [39] [40]: excellent quality (0 - 25), good quality (26 - 50), poor quality $(51-75)$, very poor quality (76 - 100), unsuitable for drinking (>100).

\subsection{Other Statistical Analysis}

The data were also statistically analyzed by using descriptive statistics, calculating the proportion of water samples with parameters above the standard, and a Spearman's rank correlation $(r)$ analysis validated with $p$-values $<0.05$. Also, the

Table 1. List of selected physicochemical parameters with WHO drinking water standard value of $i^{\text {th }}$ parameter $\left(S_{i}\right)$, proportionality constant $(K)$ and unit weight factor $\left(W_{i}\right)$.

\begin{tabular}{cccc}
\hline \multirow{2}{*}{ Parameters } & \multicolumn{3}{c}{ Water Quality Index (WQI) } \\
\cline { 2 - 4 } $\mathrm{pH}$ & $S_{i}$ & $K$ & $W_{i}$ \\
\hline $\mathrm{TDS}$ & 8.5 & 3.65 & 0.43 \\
$\mathrm{Ca}^{2+}$ & 500 & 3.65 & 0.01 \\
$\mathrm{Mg}^{2+}$ & 100 & 3.65 & 0.04 \\
$\mathrm{Na}^{+}$ & 50 & 3.65 & 0.07 \\
$\mathrm{~K}^{+}$ & 200 & 3.65 & 0.02 \\
$\mathrm{Cl}^{-}$ & 12 & 3.65 & 0.30 \\
$\mathrm{SO}_{4}^{2-}$ & 250 & 3.65 & 0.01 \\
$\mathrm{HCO}_{3}^{-}$ & 250 & 3.65 & 0.01 \\
$\mathrm{NO}_{3}^{-}$ & 120 & 3.65 & 0.03 \\
\hline
\end{tabular}


Correspondence Analysis with the test of independence between the seasons and the status of well water quality and $\mathrm{H} 0$ null hypothesis and Ha alternative hypothesis, based on a chi-square statistic (observed and critical values) at the significance level alpha $=0.05$ is done.

Finally, urban stakeholders in the interactive discussion group were involved in joint analysis to appreciate well water physicochemical and bacteriological data provided by Laboratories, statistical results and to point out their responsibility on the well water contamination in perspective to contribute to the development of groundwater security plans.

\section{Results and Discussion}

\subsection{City Metabolism and Sanitation Challenge}

To live, these cities need materials (packaging, processing, production equipment), energy (firewood, coal, electricity, fuel), food products (local or imported plant and animal products) and water as safe water provided by the National Company (139,262 $\mathrm{m}^{3} /$ day for Cotonou and $7537 \mathrm{~m}^{3} /$ day for Lomé), rainwater, water from lagoons, Lake Nokoué in Cotonou, River Zio in Lomé and Atlantic Ocean and groundwater from Continental and Quaternary aquifers.

In the cities, these resources (inputs) enter in the "regulation system" refers here to the metabolic consumption of inputs, transformation, transfer or storage. For example, the food products were consumed by human and animal or transformed by the industries. Water from the rains, River, Lake, lagoon and Atlantic Ocean entered in the Cotonou and Lomé urban system, in connection to the shallow unconfined groundwater. Otherwise, water, especially from the wells and the national network is used for washing, bathing, laundry, cleaning dishes, gardening, household cleaning and occasionally for cooking/drinking. These metabolic mechanisms (production, transformation and consumption) generated waste in different forms such as wastewater, black water (urine and faeces), greywater (effluent from shower, washing, hand basin, dishwasher and kitchen), solid waste (plastic bags, metal packaging, residues of crop products, etc.), human and animal faeces, etc.

The metabolism of the cities of Cotonou and Lomé has interactive components as the inputs of material, energy and water resources, the regulation system based on these resources (consumption, transformation, transfer or storage) and diverse wastes production. Therefore, the non-planned management of these outputs is a type of factor for groundwater pollution. The typical sanitation chains [41] in Cotonou and Lomé predominantly consist of septic tank, pit latrine, and manual transport for the management of faecal sludge.

This study focused on solid, liquid and excreta waste, for which critical management practices and absence of formal recycling mechanisms are key elements of linear urban metabolism (Figure 2) and of the contamination of groundwater. Indeed, invested urban communities link city pollution to solid waste (70\% in Cotonou and $28 \%$ in Lomé) and floods (38\% in Cotonou and $42 \%$ in Lomé). 


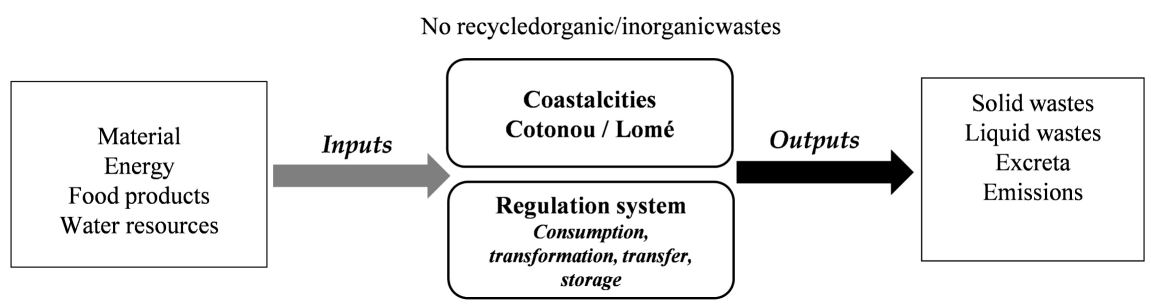

Figure 2. Linear urban metabolism in Cotonou and Lomé.

Approximately $65 \%$ of people in Cotonou and $70 \%$ in Lomé see a relationship between poor health and sanitation problems (59\% and 52\%), household solid waste $(51 \%$ and $40 \%)$ and wastewater management (30\% and $36 \%)$. Citizens' behaviors on solid waste management are burying, discharge into gutters, bridging swamps, burning, and low uptake of sanitation services. Also, wastewater and excreta management in Cotonou and in Lomé are inappropriate (Figure 3) and compromised well water bacteriological quality and its availability.

In fact, wastewater from toilets, urinals or bidets is mostly discharged into sumps and streets, whereas that from bathing, washing, laundry or washing dishes is poured into the streets, gutters and house courtyards. Pit latrine (52\%) and septic tank (32\%) are the main routes for excreta disposal and probably groundwater faecal contamination which breadth depends on season variation. Public perception translates current sanitation infrastructure in Cotonou and Lomé by personal disposal, often outdated, poorly constructed, inadequate or poorly maintained. The knowledge and attitudes of inhabitants are reflected by the lack of latrines and maintenance of garbage cans, and the dumping of waste on swamps, streets, gutters and lagoons without prior treatment.

The social appropriation of Cotonou and Lomé land is illustrated by the higher levels of environmental pollution and water system including shallow aquifers contamination. Banerjee and Morella [42] explained that only around $10 \%$ of the households of some sub-Saharan African countries live in dwellings that are connected to a sewer system. But the waste management systems continue to be inadequate with the rapid growth of urban population in these cities which consequently are experiencing groundwater contamination. As probable principal risk factors for water quality deterioration, Sitotaw and Nigus [43] included unhygienic water handling practices at the household level and poor environmental conditions around the source. Moreover, the poor quality of the faeces-contaminated water [44] [45] confirms the link between the complex environmental conditions and the poor psychosocial perceptions of the cities' inhabitants. By analyzing the relationship between the metabolism of an urban system and waste management, it is apparent that recycling is important [46] [47] [48] [49] for enhancing groundwater security.

Based on the household survey data, the outputs of urban metabolic processes constitute threats to public health and ecosystems including hydrosystems. This is confirmed in many countries where untreated wastewater and excreta pollute streets, agricultural land and freshwater bodies [50] such as shallow aquifers that 


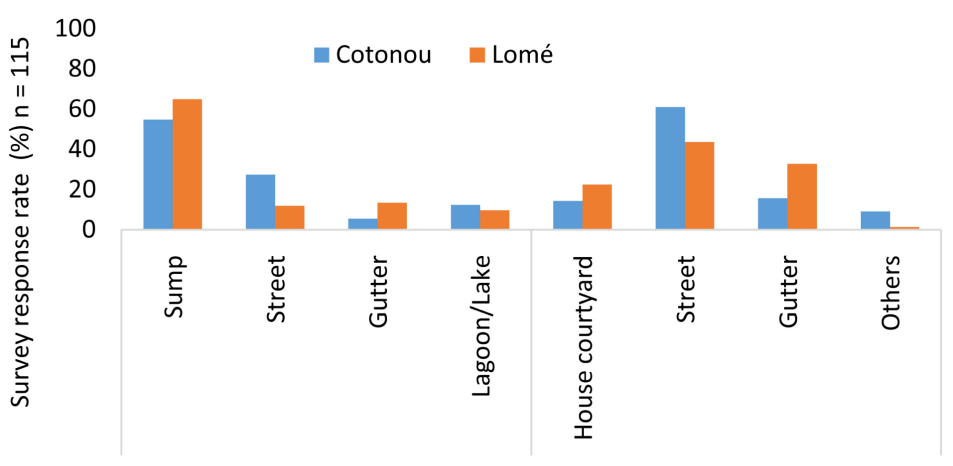

Disposals of wastewater

(a)

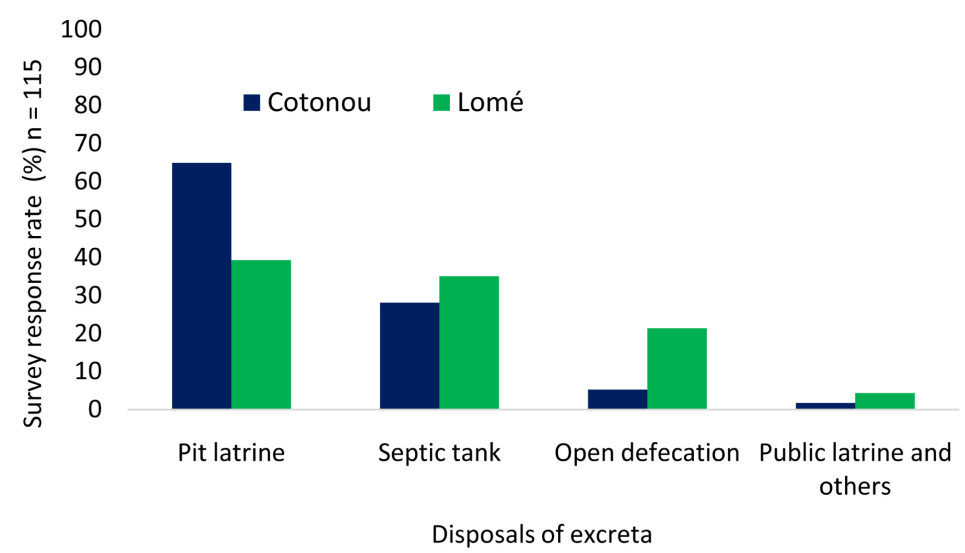

(b)

Figure 3. Practices of wastewater (a) and excreta management (b).

provide domestic water via wells. Almost $85 \%$ to $90 \%$ of global wastewater is discharged without treatment [51], leading to serious impacts on urban water supply sources. These cities are confronted with the problem of a lack of adequate infrastructure (52.3\% and 30.7\%) that supports sustainable sanitation and hygiene (Figure 4 ). In addition to being poor (30.34\% and $19.3 \%)$, residents are also unaware of sanitation and hygiene $(11.80 \%$ and $31.3 \%)$ and its implication on well water quality. Also, the level of education (4.49\% and 13.3\%) and sociocultural origin $(1.12 \%$ and $5.3 \%)$ contributes to a lesser extent to the unsafe sanitation in Cotonou and Lomé.

Referring to the lack of adequate infrastructure, WHO and United Nations International Children's Emergency Fund (UNICEF) [52] emphasized that in Sub-Saharian Africa, low proportion of population uses sewer connections (8\%), septic tanks (10\%), latrines (31\%). Also, sanitation services fail primarily evoked by Hawkins et al. [50] is an inadequate service delivery chain rather than a lack of infrastructure. More, Sijbesma et al. [53] established a link between the sanitation problem and the poor urban areas. Related studies on African city include Cotonou [54], Kampala, Dar es Salaam [55] and Lomé [44] were conducted without link to urban metabolism. Indifference to the pollution of urban space 


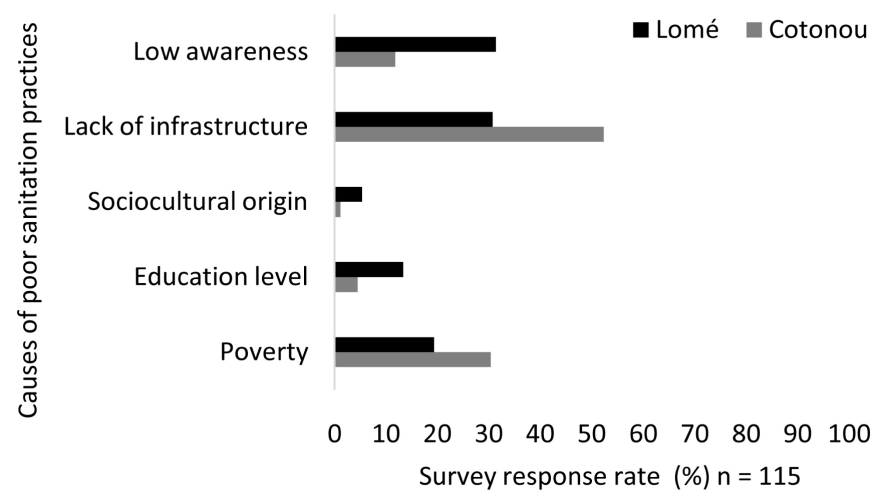

Figure 4. Perception of urban communities of the origins of poor sanitation and inappropriate hygiene.

could be interpreted as a weakness of the social bond and, more generally, the degradation of relationship between human and their city [56]. Engaging urban communities facilitate the understanding of the paradigm that urban community-based inhabitants are victims to their own ongoing sanitation behavior in a complex biophysical environment, affecting the quality of groundwater.

\subsection{Well Water Physicochemical and Bacteriological Quality Status}

A mutual collaboration for the samples collection enables to the characterization of the monitored well and to identify that most of them are often poorly maintained and unprotected against natural and anthropogenic sources of chemical and bacteriological pollution. There aren't wells with cleaner water because of the shallow water table and the high level of contamination.

\section{Physicochemical parameters}

The average values of cations and anions are in the order $\mathrm{Na}^{+}>\mathrm{Ca}^{2+}>\mathrm{K}^{+}>$ $\mathrm{Mg}^{2+}$ and $\mathrm{HCO}_{3}^{-}>\mathrm{Cl}^{-}>\mathrm{SO}_{4}^{2-}>\mathrm{NO}_{3}^{-}$in Cotonou and Lomé, highlighting that coastal environment (saltwater, carbonate materials, etc.), atmospheric processes (evaporation) and soil/water salinization or their combination impact the shallow aquifers. Therefore, the dominant cation and anion present relative different concentrations in Cotonou $\left(\mathrm{Na}^{+}: 8.2-168.9 \mathrm{mg} / \mathrm{L} ; \mathrm{HCO}_{3}^{-}: 22.0-580.7 \mathrm{mg} / \mathrm{L}\right)$ and in Lomé $\left(\mathrm{Na}^{+}: 18.0\right.$ - $\left.399.0 \mathrm{mg} / \mathrm{L} ; \mathrm{HCO}_{3}^{-}: 122.0-780.8 \mathrm{mg} / \mathrm{L}\right)$. These two cities are on the influence on the Atlantic Ocean, lagoons and lakes (an urban metabolism inputs in this case) because of their coastal location. A significant positive correlation $(\mathrm{P}<0.05)$ of $\mathrm{Na}^{+}$with TDS (0.88 in Cotonou; 0.94 in Lomé), and of $\mathrm{Cl}^{-}$with TDS (0.77 in Cotonou; 0.88 in Lomé) indicate a significant influence of the marine environment as confirmed by Sang et al. [57], of the evaporation effect on shallow groundwater (Quaternary aquifer) in the dry season or of the manmade soil salinization due to urbanization on the groundwater. The relative positive correlation between $\mathrm{HCO}_{3}^{-}$and the seawater elements as $\mathrm{Na}^{+}(0.56$ in Cotonou; 0.72 in Lomé), $\mathrm{Cl}^{-}$( 0.37 in Cotonou; 0.64 in Lomé) could be explain by the fact that [57] [58] the bicarbonate may have as origin the deposition of 
the marine sediments. Cotonou and Lomé cities are established on the marine sand deposits, contained the carbonate materials (e.g. seashells) which dissolution can explain the presence of $\mathrm{HCO}_{3}^{-}$.

The concentrations of $\mathrm{K}^{+}$(100\% of the samples) and $\mathrm{NO}_{3}^{-}(64 \%$ to $73 \%)$ are above the standards of drinking water in Lomé, whereas $\mathrm{K}^{+}(50 \%$ to $71 \%)$ and the total hardness ( $86 \%$ to $100 \%$ ) affect well water in Cotonou particularly in the great dry season. Jawadi et al. [40] attribute to the carbonates, the source of groundwater hardness. The water in Cotonou is much harder than in Lomé, exceeding the level that defines very hard water $(\geq 180 \mathrm{mg} / \mathrm{L})$. Otherwise, TDS varies from 150 to $1487 \mathrm{mg} / \mathrm{L}$ in Cotonou and from 475 to $2266 \mathrm{mg} / \mathrm{L}$ in Lomé with respectively $63.03 \%$ and $97.73 \%$ of samples presenting concentrations up to $500 \mathrm{mg} / \mathrm{L}$. TDS presents a higher average value in the great dry season in Cotonou $(759.6 \mathrm{mg} / \mathrm{L})$ and in the great rainy season in Lomé $(1202.4 \mathrm{mg} / \mathrm{L})$. Elevated TDS was referred by Jawadi et al. [40] to chemical weathering or pollution from surface activities. Among the contents of TDS, dissolved calcium and magnesium in the water contributes to the hardness [59]. With p-values $<0.05$, TH in the well water of Cotonou is positively correlated with EC (0.86), TDS and $\mathrm{Ca}^{2+}$ (0.82), $\mathrm{Mg}^{2+}(0.81)$ and $\mathrm{HCO}_{3}^{-}(0.66)$. In Lomé, $\mathrm{TH}$ is also strongly correlated with EC and TDS (0.94), $\mathrm{Ca}^{2+}(0.92), \mathrm{Mg}^{2+}(0.70), \mathrm{Na}^{+}(0.86)$ and $\mathrm{Cl}^{-}(0.84)$.

The origin of nitrates in water can be domestic sewage [60], wastewater [61], inorganic fertilizer or applications of animal manure to land and the use of pit latrines [62]. Increased concentrations of $\mathrm{NO}_{3}^{-}$ions originated from sewage and human waste, consistent with human density in the contaminated areas [63], such as the informal neighborhoods of Cotonou and Lomé. Also, latrine density is known to be a statistically significant predictor for $\mathrm{NO}_{3}^{-}$and $\mathrm{Cl}^{-}$ concentrations [64]. In the great rainy season, $\mathrm{NH}_{4}^{+}$concentrations in well water exceed the standard in Lomé but not in Cotonou. High levels of $\mathrm{NH}_{4}^{+}$or $\mathrm{NO}_{3}^{-}$in groundwater can arise from septic systems and wastewater [65], for which management practice is critical in the two investigated cities.

For Tijani and Onodera [66], the high $\mathrm{NO}_{3}^{-}$concentration in shallow aquifers in Ibadan (Nigeria) is related to leachate inputs from in-house soakaways and pit latrines.

\section{Hydrochemical facies}

Aquifers through its basic dissolved mineral substances which as sodium, calcium, magnesium, potassium, chloride, bicarbonate, and sulphate, etc. can affect groundwater quality. Changes in the chemical composition of groundwater are related to ion exchange, rock dissolution or weathering, seawater intrusion and contamination from humans and animals. These changes can help to interpret the geochemical facies of domestic well water. The major well water types in Cotonou are chlorinated, sulphated calcium and magnesium $\left(\mathrm{Ca}^{2+}-\mathrm{Mg}^{2+}-\mathrm{Cl}^{-}-\right.$ $\left.\mathrm{SO}_{4}^{2-}, 48.21 \%\right)$ and bicarbonated calcium and magnesium $\left(\mathrm{Ca}^{2+}-\mathrm{Mg}^{2+}-\mathrm{HCO}_{3}^{-}\right.$, $26.78 \%)$. In Lomé, well water is predominantly chlorinated sodium and potassium or sulphated sodium $\left(\mathrm{Na}^{+}-\mathrm{K}^{+}-\mathrm{Cl}^{-}-\mathrm{SO}_{4}^{2-}, 65.90 \%\right)$ and chlorinated, sul- 
phated calcium and magnesium $\left(\mathrm{Ca}^{2+}-\mathrm{Mg}^{2+}-\mathrm{Cl}^{-}-\mathrm{SO}_{4}^{2-}, 31.81 \%\right)$. Wen et al. [67] and Sang et al. [57] explained that in coastal aquifers, ion exchanges of $\mathrm{Ca}^{2+}$ and $\mathrm{Mg}^{2+}$ with $\mathrm{Na}^{+}$and $\mathrm{K}^{+}$from seawater enhance the dissolution of gypsum and dolomite.

The $\mathrm{Na}^{+}-\mathrm{Cl}^{-}$water in Cotonou and Lomé is related to seawater intrusion into the hydrogeological system due to relatively proximity to the Atlantic Ocean or indirectly through connected lagoons and lakes (water inflows systems). This type of water can also link the anthropogenic sources of salinization or evaporation resulting in the accumulation of salts. The $\mathrm{Ca}^{2+}-\mathrm{HCO}_{3}^{-}$type reveals the availability of fresh water in Cotonou, more so than in Lomé.

\section{Gibbs Diagrams}

The Gibbs diagram (Figure 5) showed that $89.29 \%$ of samples in Cotonou and $54.54 \%$ in Lomé on the whole seasons fell into the rock weathering dominance zone and respectively $10.71 \%$ and $45.46 \%$ into the evaporation dominance zone mostly in the dry seasons. This result suggests that water-rock interactions and rock weathering were the predominantly factors controlling the chemical composition in the study areas. The evaporation also influences well water chemistry mostly in the neighborhoods Ahouansori Towéta, Avotrou, Kpankpan and Tonato near the Lake Nokoué on Cotonou and Nyekonakpoè, Hanoukopé, Gbényedji 1, Akodessewa Kpota and Ablogamé with no specific localization on the city of Lomé.

The first Gibbs ratio (cation weight) values vary from 0.19 to 0.73 with average of 0.47 in Cotonou and 0.18 to 0.76 with average of 0.36 in Lomé while the second ratio (anion weight) values respectively from 0.11 to 0.88 with average of 0.61 and 0.25 to 0.67 with average of 0.40 . This implies cation exchange dominance on the hydrogeochemical compositions.

\section{Water Quality Index}

The estimated WQI and the status of water quality were presented in Table 2. WQI for the well water in the great rainy season (GRS), small dry season (SDS), small rainy season (SRS) and the great dry season (GDS) vary respectively from 37.3 to $144.3,35.9$ to $169.6,47.6$ to 161.0 in Cotonou and 82.94 to $364.68,94.66$ to $317.39,102.71$ to 281.81 and 91.14 to 263.77 in Lomé.

These WQI values also indicate that average of 91\% (Cotonou) and 100\% (Lomé) of well water samples fall into the poor to unsuitable for drinking categories, mostly in the dry seasons. Good water quality category is weakly represented in Cotonou with $21 \%$ in the great dry season, $7 \%$ in the small dry season and in the small rainy season. The Correspondence Analysis suggested that the chi-square observed value is lower (9.441) than the critical value (21.026). Then the p-value (0.665) above the significance level alpha $=0.05$ leads to accept the null hypothesis $\mathrm{H} 0$ of independence between the seasons and the physicochemical quality status of well water.

\section{Bacteriological parameters}

Seasonal variations in microbial content show significant concentrations of total coliforms, E. coli, faecal enterococci/streptococci and sulphite-reducing clostridia 

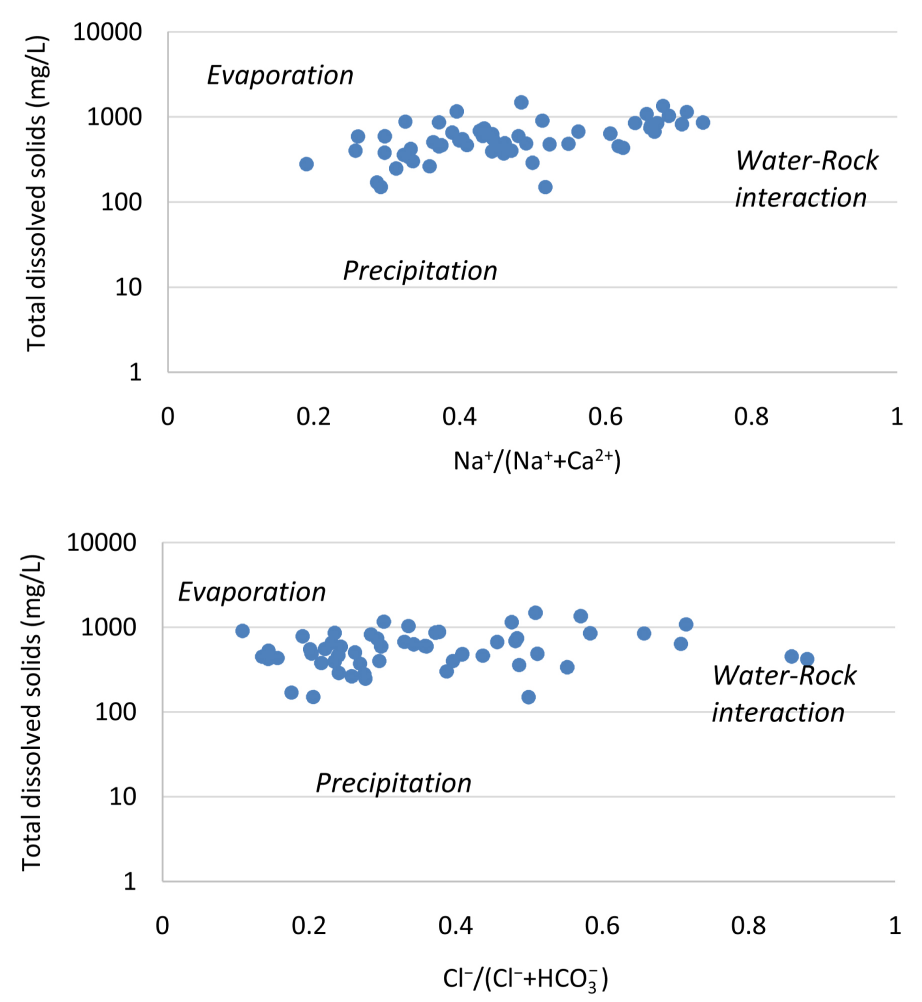

(a)
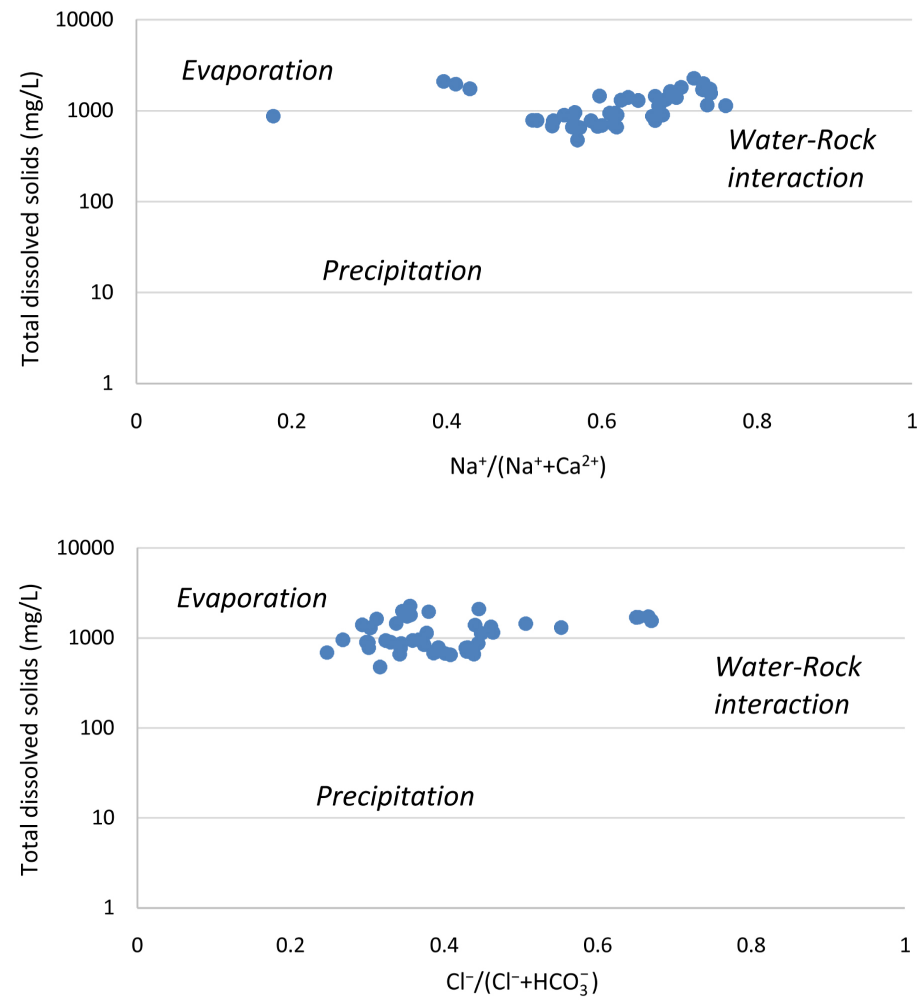

(b)

Figure 5. Gibbs diagrams with TDS vs. $\mathrm{Na}^{+} /\left(\mathrm{Ca}^{2+}+\mathrm{Na}^{+}\right)$and TDS vs. $\mathrm{Cl}^{-} /\left(\mathrm{Cl}^{-}+\mathrm{HCO}_{3}^{-}\right)$ indicating the mechanisms controlling the groundwater chemistry in: (a) Cotonou; (b) Lomé. 
Table 2. Water Quality Index (WQI), status of water quality and seasonal well water samples proportion in Cotonou and Lomé.

\begin{tabular}{|c|c|c|c|c|c|}
\hline \multirow{2}{*}{$\begin{array}{c}\text { Water Quality } \\
\text { Index level }\end{array}$} & \multirow{2}{*}{ Status } & \multicolumn{4}{|c|}{ Cotonou } \\
\hline & & GRS & SDS & SRS & GDS \\
\hline $0-25$ & Excellent water quality & $0 \%$ & $0 \%$ & $0 \%$ & $0 \%$ \\
\hline $26-50$ & Good water quality & $21 \%$ & $7 \%$ & $7 \%$ & $0 \%$ \\
\hline $51-75$ & Poor water quality & $36 \%$ & $29 \%$ & $29 \%$ & $14 \%$ \\
\hline $76-100$ & Very poor water quality & $29 \%$ & $29 \%$ & $43 \%$ & $64 \%$ \\
\hline \multirow[t]{3}{*}{$>100$} & Unsuitable for drinking & $14 \%$ & $36 \%$ & $21 \%$ & $21 \%$ \\
\hline & & \multicolumn{4}{|c|}{ Lomé } \\
\hline & & GRS & SDS & SRS & GDS \\
\hline $0-25$ & Excellent water quality & $0 \%$ & $0 \%$ & $0 \%$ & $0 \%$ \\
\hline $26-50$ & Good water quality & $0 \%$ & $0 \%$ & $0 \%$ & $0 \%$ \\
\hline $51-75$ & Poor water quality & $0 \%$ & $0 \%$ & $0 \%$ & $0 \%$ \\
\hline $76-100$ & Very poor water quality & $18 \%$ & $0 \%$ & $18 \%$ & $9 \%$ \\
\hline$>100$ & Unsuitable for drinking & $82 \%$ & $100 \%$ & $82 \%$ & $91 \%$ \\
\hline
\end{tabular}

in whole water samples, particularly in the dry seasons that promote evaporation than the rainy seasons (Table 3).

Sadhana et al. [68] have demonstrated the microbial quality of shallow groundwater statistically significantly declines during the wet season compared with in the dry season. This is related to considerable water flow and diffuse pollution from sanitation disposal. The concentration of bacteria exceeds the WHO guidelines for drinking water and reveal the higher faecal contamination of groundwater. Bacterial pollution of well water is associated with waste deposits, toilets and pit latrines located less than $5-10 \mathrm{~m}$ from the well, defective septic tanks, and wastewater-induced recharge into shallow aquifers (0.5 - $2 \mathrm{~m})$. Azzellino et al. [69] confirmed that groundwater status in highly urbanized areas is particularly affected by anthropogenic influence due to diffuse pollution originating from a number of sources. Anthropogenic sources of wastes in Cotonou and Lomé were households, crops transformation units, industries or building construction company which transfer chemical and bacteriological pollutant to groundwater system. Thus, in the context of climate change, annual flooding in Cotonou and Lomé exacerbates urban groundwater deterioration by diffuse pollution from inappropriate and informal sanitation disposal (e.g., pit latrine, sump, gutter, domestic sewage, landfills). Sadhana et al. [67] reasoned that two hydrological processes were responsible for the seasonal variation: infiltration of contaminants and change in the water level below the ground surface. The dominant sandy soils in Cotonou and Lomé and the shallow level of groundwater seem to support this hypothesis of environmental factors contribution in the groundwater quality degradation. 
Table 3. Seasonal mean values, maximum and minimum of bacteriological parameters assessed on the well water.

\begin{tabular}{|c|c|c|c|c|c|c|c|}
\hline \multirow{2}{*}{ Parameter } & \multirow{2}{*}{$\begin{array}{l}\text { WHO } \\
\text { guideline }\end{array}$} & \multicolumn{6}{|c|}{ Cotonou } \\
\hline & & GRS & SDS & SRS & GDS & $\operatorname{Max}$ & Min \\
\hline Total coliforms (UFC/100mL) & 0 & 360 & 249 & 464 & 875 & 1812 & 112 \\
\hline Escherichia coli (UFC/100mL) & 0 & 243 & 145 & 200 & 333 & 780 & 40 \\
\hline $\begin{array}{l}\text { Faecal enterococci/streptococci } \\
\text { (UFC/100mL) }\end{array}$ & 0 & 286 & 188 & 124 & 285 & 736 & 18 \\
\hline \multirow[t]{3}{*}{$\begin{array}{l}\text { Sulphite reducing clostridia } \\
\qquad(\mathrm{UFC} / 20 \mathrm{~mL})\end{array}$} & 0 & 23 & 17 & 19 & 8 & 112 & 0 \\
\hline & & \multicolumn{6}{|c|}{ Lomé } \\
\hline & & GRS & SDS & SRS & GDS & Max & Min \\
\hline Total coliforms (UFC/100mL) & 0 & 114 & 108 & 75 & 50 & 1000 & 1 \\
\hline Escherichia coli (UFC/100mL) & 0 & 12 & 1 & 7 & 1 & 112 & 1 \\
\hline $\begin{array}{l}\text { Faecal enterococci/streptococci } \\
(\mathrm{UFC} / 100 \mathrm{~mL})\end{array}$ & 0 & 6 & 19 & 6 & 13 & 118 & 1 \\
\hline $\begin{array}{l}\text { Sulphite reducing clostridia } \\
\text { (UFC/20mL) }\end{array}$ & 0 & 3 & 10 & 2 & 12 & 74 & 1 \\
\hline
\end{tabular}

In the whole, less waste collection (43.48\% subscribers to waste collection service in Cotonou and $67.8 \%$ in Lomé) and unsafe sanitation and unhygienic disposal, particularly in the slums, give rise to an unsatisfactory microbiological profile. This water is unfit for human consumption, but for other uses it might be suitable. Lapworth et al. [70] also showed that the quality of shallow urban groundwater resources in sub-Saharan Africa is often very poor due to inadequate waste management and source protection, and poses a significant health risk to users. In Cotonou and Lomé, immersion of urban communities in their own environment helps to identify more cause-and-effect relationships between unsafe sanitation and unhygienic systems and their environment, groundwater and public health. According to UNICEF [71], poor WASH is the main causes of faecally transmitted infections, including cholera and other diarrhoeal diseases.

Empowering urban communities to learn about environmental management guided by this research could help to engage them as part of the sustainable solutions, the detailed aspects of which will be the focus of the future research.

The participatory transdisciplinary approach was useful to better understand the connexion society-ecology-hydrology by integrating social aspects into hydrogeochemical investigations but knowledge production though its application could be influenced by the leadership of the academics.

\section{Conclusions}

This study established the relationship between each component of the steps of urban metabolism with groundwater quality. Sometimes, groundwater contamination is associated with solid, liquid wastes and excreta (outflows). But the 
contamination starts at the level of the inflows with for example saltwater as a pollutant, continues with the regulation system before been accentuated by the outflows as divers wastes.

The study findings revealed that Cotonou and Lomé cities face rapid transformation with considerable flow of materials, energy, water and people, and show evidence of high production and concentration of metabolic wastes in saturated and confined urban areas. This ecological footprint and the lack of waste recycling lead to linear urban metabolism characterized by waste burning, burying, and discharge to gutters and swamps. Then, by faecal and chemical contamination, these unsafe practices affect the shallow Quaternary aquifer from which citizens extract water through domestic wells. Hence, the well water quality in Cotonou and Lomé is very bacteriologically poor, with the presence of total coliforms, E. coli, faecal enterococci/streptococci and sulphite-reducing clostridia) in high concentrations.

The physicochemical status of water quality is dominated by the $\mathrm{Ca}^{2+}-\mathrm{Mg}^{2+}-\mathrm{Cl}^{-}$$\mathrm{SO}_{4}^{2-}$ and $\mathrm{Na}^{+}-\mathrm{Cl}^{-}$types. Gibbs diagram highlights water-rock interactions and rock weathering as the mean factor controlling the well water chemical composition and estimated WQI values indicate very poor water quality to unsuitable for drinking in the both cities.

The co-produced knowledge by the effective inclusion of the urban communities in hydrogeological investigations in the changing city will help shift the urban metabolism from a linear (vicious) mode to a circular (virtuous) one by controlling the identified sources of groundwater pollution. Protection and sustainability of groundwater quality in the coastal cities of sub-Saharan Africa will proceed by the development of adaptable socio-ecological systems of sanitation and safe hygiene practices. Also, measures such as drilling wells deeper, removing landfills from the vicinity of wells, fencing wells and so on could help to sustain a safe well water supply.

\section{Acknowledgements}

This work is based on research supported wholly by the LIRA 2030 Africa Programme, which is implemented by the International Science Council (ISC) in partnership with the Network of African Science Academies (NASAC), with support from the Swedish International Development Cooperation Agency (Sida).

This research has been approved by the Ethical Committee of Biomedical Research, University of Parakou, Benin (Ref. No. 0299/CLERB-UP/P/SP/SA of 14/ 05/2020). Informed consent was obtained from each participant before their inclusion on the transdisciplinary research team.

\section{Conflicts of Interest}

The authors declare no conflicts of interest regarding the publication of this paper. 


\section{References}

[1] Bancheva, S. (2014) Integrating the Concept of Urban Metabolism into Planning of Sustainable Cities. Analysis of the $\mathrm{Eco}^{2}$ Cities Initiative. DPU Working Paper No. 168, University College London, London.

[2] Saguin, K. (2019) Urban Metabolism. In: Orum, M.A., Ed., Wiley Blackwell Encyclopedia of Urban and Regional Studies, Wiley-Blackwell, Hoboken, 1-5. https://doi.org/10.1002/9781118568446.eurs0378

[3] Doughty, M.R.C. and Hammond, G.P. (2004) Sustainability and the Built Environment at and beyond the City Scale. Building and Environment, 39, 1223-1233. https://doi.org/10.1016/j.buildenv.2004.03.008

[4] Musango, J.K., Currie, P. and Robinson, B. (2017) Urban Metabolism for Resource Efficient Cities: From Theory to Implementation. UN Environment, Paris.

[5] Longato, D., Lucertini, G., Fontana, D.M. and Musco, F. (2019) Including Urban Metabolism Principles in Decision-Making: A Methodology for Planning Waste and Resource Management. Sustainability, 11, 2101. https://doi.org/10.3390/su11072101

[6] Blunier, P. (2009) Méthodologie de gestion durable des ressources du sous-sol urbain (Methodology for the Sustainable Management of Urban Subsoil Resources). Ph.D. Thesis, École Polytechnique Fédérale de Lausanne, Suisse.

[7] UN-Habitat (2014) The State of African Cities 2014: Re-Imagining Sustainable Urban Transitions. UN-Habitat, Nairobi.

[8] Guneralp, B., Lwasa, S., Masundire, H., Parnell, S. and Seto, C.K. (2018) Urbanization in Africa: Challenges and Opportunities for Conservation. Environmental Research Letters, 13, Article ID: 015002.

https://doi.org/10.1088/1748-9326/aa94fe

[9] Smit, W. (2018) Urban Governance in Africa: An Overview. International Development Policy. Revue internationale de politique de développement, 10, 55-77.

https://doi.org/10.4000/poldev.2637

[10] Bochet, B. and Da Cunha, A. (2003) Métropolisation, forme urbaine et développement durable (Metropolization, Urban Form and Sustainable Development). In: Da Cunha, A. and Ruegg, J., Eds., Développement durable et aménagement du territoire, Presses Polytech-niques et Universitaires Romandes: Lausanne, Suisse, 83-100.

[11] Deutsche Gesellschaft für Internationale Zusammenarbeit (GIZ) (2019) Access to Water and Sanitation in Sub-Saharan Africa. Review of Sector Reforms and Investments, Key Findings to Inform Future Support to Sector Development. Part I-Synthesis Report, Berlin.

[12] United Nations Environment Programme (UNEP) (2016) Snapshot of the World's Water Quality. UNEP, Nairobi.

[13] Chen, S., Tang, Z., Wang, J., Wu, J., Yang, C., Kang, W. and Huang, X. (2020) Multivariate Analysis and Geochemical Signatures of Shallow Groundwater in the Main Urban Area of Chongqing, Southwestern China. Water, 12, 2833. https://doi.org/10.3390/w12102833

[14] d'Oliveira, F.M. (2021) Qualité des eaux souterraines, facteurs de détérioration et risques sanitaires dans la ville de Cotonou (Bénin) (Groundwater Quality, Deterioration Factors and Health Risks in the City of Cotonou (Benin)). Master's Thesis, Université d'Abomey-Calavi, Cotonou.

[15] Maliki, A.R. (1993) Etude hydrologique du littoral béninois dans la région de Co- 
tonou (Afrique de l'Ouest) (Hydrological Study of the Benin Coastline in the Cotonou Region (West Africa)). Ph.D. Thesis, Université Cheick Anta Diop, Dakar.

[16] Eka, A.B. (2021) Qualité des eaux souterraines, facteurs de détérioration et risques sanitaires dans la ville de Lomé (Groundwater Quality, Deterioration Factors and Health Risks in the City of Lomé). Master's Thesis, Université de Lomé, Lomé.

[17] Boukari, M. (1998) Fonctionnement du système aquifère exploité pour l'approvisionnement en eau de la ville de Cotonou sur le littoral béninois. Impact du développement urbain sur la qualité des ressources (Functioning of the Aquifer System Used for the Water Supply of the City of Cotonou on the Benin Coast. Impact of Urban Development on the Quality of Resources). Ph.D. Thesis, Université Cheick Anta Diop, Dakar.

[18] Gnazou, M.D.-T., Sabi, E.B., Tairou, S.M., Akakpo, W., Agouda, K., Upton, K., Dochartaigh, Ó.B. and Bellwood-Howard, I. (2021) Africa Groundwater Atlas: Hydrogeology of Togo. British Geological Survey.

http://earthwise.bgs.ac.uk/index.php/Hydrogeology_of_Togo

[19] Sivapalan, M., Savenije, H. and Bloeschl, G. (2012) Sociohydrology: A New Science of People and Water. Hydrological Processes, 26, 1270-1276.

https://doi.org/10.1002/hyp.8426

[20] Re, V. (2015) Incorporating the Social Dimension into Hydrogeochemical Investigations for Rural Development: The Bir Al-Nas Approach for Socio-Hydrogeology. Hydrogeology Journal, 23, 1293-1304. https://doi.org/10.1007/s10040-015-1284-8

[21] Barles, S. (2002) Le métabolisme urbain et la question écologique (Urban Metabolism and the Ecological Question). Les Annales de la Recherche Urbaine, 92, 143-150. https://doi.org/10.3406/aru.2002.2469

[22] Kennedy, C., Pinceti, S. and Bunje, P. (2011) The Study of Urban Metabolism and Its Applications to Urban Planning and Design. Environmental Pollution, 159, 1965-1973. https://doi.org/10.1016/j.envpol.2010.10.022

[23] Mostafavi, N., Farzinmoghadam, M., Hoque, S. and Weil, B. (2014) Integrated Urban Metabolism Analysis Tool (IUMAT). Urban Policy and Research, 32, 53-69. https://doi.org/10.1080/08111146.2013.826578

[24] Beloin-Saint-Pierre, D., Rugani, B., Lasvaux, S., Mailhac, A., Popovici, E., Sibiude, G., Benetto, E. and Schiopu, N.A. (2016) Review of Urban Metabolism Studies to Identify Key Methodological Choices for Future Harmonization and Implementation. Journal of Cleaner Production, 163, S223-S240.

https://doi.org/10.1016/j.jclepro.2016.09.014

[25] Lang, J.D., Wiek, A., Bergmann, M., Stauffacher, M., Martens, P., Moll, P., Swilling, M. and Thomas, J.C. (2012) Transdisciplinary Research in Sustainability Science: Practice, Principles, and Challenges. Sustainability Science, 7, 25-43.

https://doi.org/10.1007/s11625-011-0149-x

[26] Jahn, T., Bergmann, M. and Keil, F. (2012) Transdisciplinarity: Between Mainstreaming and Marginalization. Ecological Economics, 79, 1-10.

https://doi.org/10.1016/j.ecolecon.2012.04.017

[27] Mauser, W., Klepper, G. and Rice, M. Schmalzbauer, B.S., Hackmann, H., Leemans, R. and Moore, H. (2013) Transdisciplinary Global Change Research: The Co-Creation of Knowledge for Sustainability. Current Opinion in Environmental Sustainability, 5, 420-431. https://doi.org/10.1016/j.cosust.2013.07.001

[28] Brandt, P., Ernst, A., Gralla, F., Luederitz, C., Lang, D.J., Newig, J., Reinert, F., Abson, J.D. and Wehrden, V.H. (2013) A Review of Transdisciplinary Research in 
Sustainability Science. Ecological Economics, 92, 1-15. https://doi.org/10.1016/j.ecolecon.2013.04.008

[29] Lin, L., Liu, M., Luo, F., Wang, K., Zhang, Q. and Xiang, W.-N. (2012) Comment on "The Study of Urban Metabolism and Its Applications to Urban Planning and Design" by Kennedy et al. (2011). Environmental Pollution, 167, 184-185. https://doi.org/10.1016/j.envpol.2012.04.011

[30] Barcelona, M., Gibb, P.J., Helfrich, A.J. and Garske, E.E. (1985) Practical Guide for Groundwater Sampling. Illinois State Water Survey (ISWS), Contrast Report 374.

[31] Hounslow, W.A. (1995) Water Quality Data. Analysis and Interpretation. Lewis Publishers, New York.

[32] World Health Organization (WHO) (2017) Guidelines for Drinking-Water Quality: Fourth Edition Incorporating the First Addendum. World Health Organization, Geneva.

[33] Piper A.M. (1944) A Graphic Procedure in the Geochemical Interpretation of Water Analysis. Eos, Transactions American Geophysical Union, 25, 914-923. https://doi.org/10.1029/TR025i006p00914

[34] Zhang, Y., Xu, M., Li, X., Qi, J., Zhang, Q., Guo, J., Yu, L. and Zhao, R. (2018) Hydrochemical Characteristics and Multivariate Statistical Analysis of Natural Water System: A Case Study in Kangding County, Southwestern China. Water, 10, 80. https://doi.org/10.3390/w10010080

[35] Gibbs, J.R. (1970) Mechanisms Controlling World Water Chemistry. Science, 170, 1088-1090. https://doi.org/10.1126/science.170.3962.1088

[36] Alastal, K.M., Alagha, J.S., Abuhabib, A.A. and Ababou, R. (2015) Groundwater Quality Assessment Using Water Quality Index (WQI) Approach: Gaza Coastal Aquifer Case Study. Journal of Engineering and Technology Research, 2, 80-86.

[37] El Baba, M., Kayastha, P., Huysmans, M. and De Smedt, F. (2020) Evaluation of the Groundwater Quality Using the Water Quality Index and Geostatistical Analysis in the Dier al-Balah Governorate, Gaza Strip, Palestine. Water, 12, 262. https://doi.org/10.3390/w12010262

[38] Etim, E., Odoh, R., Itodo, A., Umoh, S.D. and Lawal, U. (2013) Water Quality Index for the Assessment of Water Quality from Different Sources in the Niger Delta Region of Nigeria. Frontiers in Science, 3, 89-95.

[39] El Tahlawi, M.R., Abo-El Kassem, M., Baghdadi, G.Y. and Saleem, H.A. (2016) Estimating and Plotting of Groundwater Quality Using WQIUA and GIS in Assiut Governorate, Egypt. World Journal of Engineering and Technology, 4, 59-70. https://doi.org/10.4236/wjet.2016.41007

[40] Jawadi, H.A., Sagin, J. and Snow, D.D. (2020) A Detailed Assessment of Groundwater Quality in the Kabul Basin, Afghanistan, and Suitability for Future Development. Water, 12, 2890. https://doi.org/10.3390/w12102890

[41] Daudey, L. (2018) The Cost of Urban Sanitation Solutions: A Literature Review. Journal of Water, Sanitation and Hygiene for Development, 8, 176-195. https://doi.org/10.2166/washdev.2017.058

[42] Banerjee, S.G. and Morella, E. (2011) Africa's Water and Sanitation Infrastructure: Access, Affordability, and Alternatives. World Bank, Washington DC. https://doi.org/10.1596/978-0-8213-8457-2

[43] Sitotaw, B. and Nigus, M. (2021) Bacteriological and Physicochemical Quality of Drinking Water in Kobo Town, Northern Ethiopia. Journal of Water, Sanitation and Hygiene for Development, 11, 271-281. 
https://doi.org/10.2166/washdev.2021.218

[44] Soncy, K.B., Anani, K., Eklou-Lawson, M., Adjrah, Y., Karou, D.S., Ameyapoh, Y. and de Souza, C. (2015) Évaluation de la qualité bactériologique des eaux de puits et de forage à Lomé, Togo (Assessment of the Bacteriological Quality of Well and Borehole Water in Lomé, Togo). Journal of Applied Biosciences, 91, 8464-8469. https://doi.org/10.4314/jab.v91i1.6

[45] Hounsounou, E.O., Tchibozo, M.A.D., Kelome, N.C., Vissin, E.W., Mensah, G.A. and Agbossou, E. (2016) Pollution des eaux à usages domestiques dans les milieux urbains défavorisés des pays en développement: Synthèse bibliographique (Pollution of Water for Domestic Use in Disadvantaged Urban Areas of Developing Countries: Bibliographical Summary). International Journal of Biological and Chemical Sciences, 10, 2392-2412. https://doi.org/10.4314/ijbcs.v10i5.35

[46] Minx, J.C., Creutzig, F., Medinger, V., Ziegler, T., Owen, A. and Baiocchi, G. (2011) Developing a Pragmatic Approach to Assess Urban Metabolism in Europe-A Report to the European Environment Agency. Technische Universität Berlin, Germany/Stockholm Environment Institute, Sweden.

[47] Hofmann, P. (2013) Wasted Waste Disappearing Reuse at the Peri-Urban Interface. Environmental Science and Policy, 31, 13-22.

https://doi.org/10.1016/j.envsci.2013.03.011

[48] Faraud, C. (2017) Urban Metabolism in Practice. The Difficult Implementation of Closing the Loop Approaches, through the Water and Food Cycles in Cities. Development Planning Unit Working Paper No. 186, University College, London.

[49] Andersson, K., Rosemarin, A., Lamizana, B., Kvarnström, E., McConville, J., Seidu, R., Dickin, S. and Trimmer, C. (2016) Sanitation, Wastewater Management and Sustainability: From Waste Disposal to Resource Recovery. United Nations Environment Programme and Stockholm Environment Institute, Nairobi, Stockholm.

[50] Hawkins, P., Blackett, I. and Heymans, C. (2013) Targeting the Urban Poor and Improving Services in Small Towns. Poor-Inclusive Urban Sanitation: An Overview. Water and Sanitation Program. Washington DC.

[51] Corcoran, E., Nellemann, C., Baker, E., Bos, R., Osborn, D. and Savelli, H. (2010) Sick Water? The Central Role of Wastewater Management in Sustainable Development. United Nations Environment Programme/United Nations Human Settlements Programme/GRID-Arendal (UNEP/UNHabitat).

[52] WHO/UNICEF (2019) Progress on Household Drinking Water, Sanitation and Hygiene 2000-2017. Special Focus on Inequalities. United Nations Children's Fund (UNICEF) and World Health Organization, New York.

[53] Sijbesma, C., Diaz, C., Fonseca, C. and Pezon, C. (2008) Financing Sanitation in Poor Urban Areas. In: Verhagen, J., da Silva Wells, C., Krukkert, I., McIntyre, P. and Ryan, P., Eds., Sanitation for the Urban Poor Partnerships and Governance, IRC Symposium, Delft, the Netherlands, 19-21 November 2008. IRC International Water and Sanitation Centre, Hague, 137-161.

[54] Odoulami, L. (2009) Problématique de l'eau potable et la santé humaine dans la ville de Cotonou (République du Bénin) (Problem of Drinking Water and Human Health in the City of Cotonou (Republic of Benin)). Ph.D. Thesis, Université d'Abomey-Calavi, Cotonou.

[55] Isunju, J., Etajak, S., Mwalwega, B., Kimwaga, R., Atekyereza, P., Bazeyo, W. and Ssempebwa, J. (2013) Financing of Sanitation Services in the Slums of Kampala and Dar es Salaam. Health, 5, 783-791. https://doi.org/10.4236/health.2013.54104

[56] Programme Solidarité Eau (pS-Eau) (2004) Gestion durable des déchets et de 
l'assainissement urbain (Sustainable Management of Waste and Urban Sanitation). Synthesis Report, Cotonou.

[57] Sang, S., Dai, H., Hu, B.X., Hao, Y., Zhou, T. and Zhang, J. (2019) The Study of Hydrogeochemical Environments and Microbial Com-Munities along a Groundwater Salinity Gradient in the Pearl River Delta, China. Water, 11, 804. https://doi.org/10.3390/w11040804

[58] Wang, Y. and Jiao, J.J. (2012) Origin of Groundwater Salinity and Hydrogeochemical Processes in the Confined Quaternary Aquifer of the Pearl River Delta, China. Journal of Hydrology, 438, 112-124. https://doi.org/10.1016/j.jhydrol.2012.03.008

[59] Mohammad, R.I., Mohammad, K.I.S., Tanzina, A., Shafkat, S.R., Rabiul, I.T., Barun, K.H. and Md. Abdul, K. (2016) A Study on Total Dissolved Solids and Hardness Level of Drinking Mineral Water in Bangladesh. American Journal of Applied Chemistry, 4, 164-169. https://doi.org/10.11648/j.ajac.20160405.11

[60] Xue, Y., Song, J., Zhang, Y., Kong, F., Wen, M. and Zhang, G. (2016) Nitrate Pollution and Preliminary Source Identification of Surface Water in a Semi-Arid River Basin, Using Isotopic and Hydrochemical Approaches. Water, 8, 328. https://doi.org/10.3390/w8080328

[61] Khatri, N. and Tyagi, S. (2015) Influences of Natural and Anthropogenic Factors on Surface and Groundwater Quality in Rural and Urban Areas. Frontiers in Life Science, 8, 23-39. https://doi.org/10.1080/21553769.2014.933716

[62] Kortatsi, K.B., Anku, A.S.Y. and Anornu, K.G. (2009) Characterization and Appraisal of Facets Influencing Geochemistry of Groundwater in the Kulpawn Sub-Basin of the White Volta Basin, Ghana. Environmental Geology, 58, 1349-1359. https://doi.org/10.1007/s00254-008-1638-9

[63] Mohammad, Z., Cepuder, P., Loiskandl, W. and Stumpp, C. (2019) Source Identification of Nitrate Contamination in the Urban Aquifer of Mashhad, Iran. Journal of Hydrology: Regional Studies, 25, Article ID: 100618.

https://doi.org/10.1016/j.ejrh.2019.100618

[64] Martínez-Santosa, P., Martín-Loechesb, M., García-Castrob, N., Solerac, D., DíazAlcaidea, S., Monteroa, E. and García-Rincónb, J. (2017) A Survey of Domestic Wells and Pit Latrines in Rural Settlements of Mali: Implications of On-Site Sanitation on the Quality of Water Supplies. International Journal of Hygiene and Environmental Health, 220, 1179-1189. https://doi.org/10.1016/j.ijheh.2017.08.001

[65] Lindenbaum, J. (2012) Identification of Sources of Ammonium in Groundwater Using Stable Nitrogen and Boron Isotopes in Nam Du, Hanoi. Thesis in Geology, Lund University, Hanoi.

[66] Tijani, M.N. and Onodera, S.I. (2005) Surface and Groundwater Qualities in an Urbanized Catchment: Scenario from a Developing Country. IAHS Publishing, Wallingford, 506-516.

[67] Wen, X., Diao, M., Wang, D. and Gao, M. (2012) Hydrochemical Characteristics and Salinization Processes of Groundwater in the Shallow Aquifer of Eastern Laizhou Bay, China. Hydrological Processes, 26, 2322-2332.

https://doi.org/10.1002/hyp.8362

[68] Sadhana, S., Takashi, N., Rabin, M. and Kei, N. (2014) Seasonal Variation in the Microbial Quality of Shallow Groundwater in the Kathmandu Valley, Nepal. Water Science and Technology: Water Supply, 14, 390-397.

https://doi.org/10.2166/ws.2013.213 
[69] Azzellino, A., Colombo, L., Lombi, S., Marchesi, V., Piana, A., Andrea, M. and Alberti, L. (2019) Groundwater Diffuse Pollution in Functional Urban Areas: The Need to Define Anthropogenic Diffuse Pollution Background Levels. Science of the Total Environment, 656, 1207-1222. https://doi.org/10.1016/j.scitotenv.2018.11.416

[70] Lapworth, J. D., Nkhuwa, W.C.D., Okotto-Okotto, J., Pedley, S., Stuart, E.M., Tijani, N.M. and Wright, J. (2017) Urban Groundwater Quality in Sub-Saharan Africa: Current Status and Implications for Water Security and Public Health. Hydrogeology Journal, 25, 1093-1116. https://doi.org/10.1007/s10040-016-1516-6

[71] UNICEF (2016) Strategy for Water, Sanitation and Hygiene 2016-2030. New York. 